\title{
PENGARUH SEDIAAN DEKOK DAUN ZAITUN (Olea europaea L.) TERHADAP PENURUNAN TEKANAN DARAH PADA TIKUS PUTIH GALUR WISTAR (Rattus norvegicus strain wistar) JANTAN YANG DIINDUKSI NATRIUM KLORIDA 5,5\%
}

\author{
Titik Kusumawinakhyu ${ }^{1,}$ Fachri Mubarok ${ }^{2}$, Yenni Bahar ${ }^{3}$, \\ ${ }^{1,3}$ Dosen Fakultas Kedokteran, Universitas Muhammadiyah Purwokerto \\ ${ }^{2}$ Mahasiswa Fakultas Kedokteran, Universitas Muhammadiyah Purwokerto \\ titikkusumawinakhyu@gmail.com
}

\begin{abstract}
According to WHO hypertension about $26.4 \%$ of world population who have suffered hypertension. It would probably increase up to $29.2 \%$ in 2025 . Usually, hypertension medical care uses convensional medicine, however it possesses some side effects and could cause complication. For that reason, herbal medicine is needed for safer and more effective purpose. One of herbal medicines is olive leaf (Olea europea L). It aimed to figure out effect of olive leaf extract (Olea europaea L.) on declining blood pressure in white male rat wistar strain (Rattus novergicus strain wistar) after 5.5\% Natrium Chloride $(\mathrm{NaCl})$ induction. 24 of rats were divided into 4 groups of treatments and $5.5 \%$ $\mathrm{NaCl}$ inductions. Group I, as a control with aquadest treatment, Group II was inducted with 540 mgs of olive leaf extract, Group III was inducted with $1080 \mathrm{mgs}$ of olive leaf extract, and Group IV was inducted with $2160 \mathrm{mgs}$ of olive leaf extract. Data were Analyzed by One way ANOVA then followed with Post-hoc test using Least Significant Differences (LSD) test. From the group I, the mean of pretest was $117.83 / 150.83 \mathrm{mmHg}$ and the mean of post test was $117.83 / 141.67 \mathrm{mmHg}$. Group II, the mean of pretest was $123.67 / 156,00 \mathrm{mmHg}$ and the mean of post test was $87.00 / 116,00 \mathrm{mmHg}$. Group III, the mean of pretest was $123.50 / 156.83 \mathrm{mmHg}$ and the mean of post test was and the mean of post test was $81.67 / 112,50 \mathrm{mmHg}$. Group IV the mean of pretest was $119.00 / 156.50 \mathrm{mmHg}$ and the mean of post test was $80.00 / 105.00 \mathrm{mmHg}$. There were effects of olive leaf extract (Olea europaea L.) in 540 mgs, $1080 \mathrm{mgs}$ and $2160 \mathrm{mgs}$ to blood pressure declining in white male rat wistar strain (Rattus novergicus strain wistar) after 5.5\% Natrium Chloride $(\mathrm{NaCl})$ induction. The higest blood pressure declining was in Group IV of 2160 mg olive leaf extract induction.
\end{abstract}

Keywords: Olea europaea L., Rattus novergicus strain wistar, blood pressure decrease, 5.5\% Natrium Chlorida.

\begin{abstract}
Abstrak
WHO menyebutkan sekitar 972 orang atau 26,4\% orang di dunia menderita hipertensi, hal tersebut kemungkinan akan terus terjadi peningkatan pada tahun 2025 hingga 29,2\%. Penggunaan obat konvensional memiliki efek samping dan dapat menyebabkan komplikasi pada pemakaian jangka panjang, sehingga memerlukan pengobatan herbal yang lebih aman untuk digunakan dan efektif terhadap penyakit. Salah satu tanaman herbal tersebut adalah daun zaitun (Olea europaea L.) Untuk mengetahui pengaruh sediaan dekok daun zaitun (Olea europaea L.) terhadap penurunan tekanan darah. Sebanyak 24 ekor tikus dibagi dalam 4 kelompok perlakuan dan diinduksi $\mathrm{NaCl} 5,5 \%$. Data dianalisis menggunakan One way ANOVA diikuti uji Post-hoc menggunakan uji Least Significant Differences (LSD). Kelompok I didapatkan rata-rata hasil pretest $117,83 / 150,83 \mathrm{mmHg}$ dan rata-rata hasil post test $117,83 / 141,67 \mathrm{mmHg}$. Kelompok II didapatkan rata-rata hasil pretest $123,67 / 156,00 \mathrm{mmHg}$ dan rata-rata hasil post test $87,00 / 116,00 \mathrm{mmHg}$. Kelompok III didapatkan rata-rata hasil pretest $123,50 / 156,83 \mathrm{mmHg}$ dan rata-rata hasil post test $81,67 / 112,50 \mathrm{mmHg}$. Kelompok IV didapatkan rata-rata hasil pretest $119,00 / 156,50 \mathrm{mmHg}$ dan rata-rata hasil post test 80,00/105,00. Terdapat pengaruh sediaan dekok daun zaitun (Olea europaea L.) dengan dosis 540mg, 1080mg dan $2160 \mathrm{mg}$ terhadap penurunan tekanan darah tikus putih galur wistar (Rattus novergicus strain wistar) jantan yang diinduksi natrium klorida 5,5\%. Penurunan tekanan darah terbesar didapatkan pada kelompok IV dengan dosis $2160 \mathrm{mg}$.
\end{abstract}

Kata kunci : Olea europaea L., Rattus novergicus strain wistar, penurunan tekanan darah, natrium klorida 5,5\% 


\section{PENDAHULUAN}

Tekanan darah tinggi sering juga disebut hipertensi, WHO menyebutkan sekitar 972 orang atau $26,4 \%$ orang di dunia menderita hipertensi, hal tersebut kemungkinan akan terus terjadi peningkatan pada tahun 2025 hingga 29,2\%. Dari 972 penderita hipertensi, terbagi atas 333 dinegara maju dan terdapat 639 lebihnya terdapat dinegara berkembang ${ }^{1}$. Berdasarkan riskesdas tahun 2013 dengan menggunakan unit analisis individu menunjukan bahwa secara nasional $25,8 \%$ penduduk Indonesia menderita penyakit hipertensi ${ }^{2}$.

Tekanan darah termasuk salah satu parameter vital diantara tanda - tanda vital tubuh, yaitu denyut nadi, pernafasan, suhu tubuh, tinggi, dan berat badan ${ }^{3}$. Hipertensi adalah sindroma yang kemudian akan memicu pengerasan pembuluh darah sampai terjadi kerusakan target organ terkait. Ada banyak faktor risiko yang berberperan, salah satunya konsumsi makanan. Konsumsi makanan yang memicu terjadinya hipertensi diantaranya adalah konsumsi makanan asin, konsumsi makanan manis, dan makanan berlemak $^{4}$.
Penatalaksanaan tekanan darah

tinggi atau hipertensi biasanya menggunakan obat konvensional, namun penggunaan obat konvensional memiliki efek samping dan dapat menyebabkan komplikasi pada pemakain jangka panjang, sehingga memerlukan pengobatan herbal yang lebih aman untuk digunakan dan efektif terhadap penyakit. Salah satu tanaman herbal tersebut adalah daun zaitun (Olea europaea L. $)^{5}$.

Berdasarkan latar belakang tersebut maka rumusan masalah pada penelitian ini adalah apakah apakah terdapat pengaruh sediaan dekok daun zaitun (Olea europaea L.) terhadap penurunan tekanan darah pada tikus putih galur wistar (Rattus novergicu strain wistar) jantan yang diinduksi natrium klorida 5,5\%. Tujuan penelitian ini untuk mengetahui pengaruh sediaan dekok daun zaitun (Olea europaea L.) terhadap penurunan tekanan darah pada tikus putih galur wistar (Rattus novergicus strain wistar) jantan yang diinduksi natrium klorida 5,5\%. 
Gambar 1. Rata-rata Tekanan Darah Sistol Tikus

\section{Wistar Jantan}

\section{METODE}

Penelitian ini merupakan penelitian eksperimental laboratorium pretest and post test with control group design. Penelitian dilakukan pada bulan Juni sampai bulan Juli 2017 di Laboratorium Farmakologi Universitas Jendral Soedirman. Sebanyak 24 ekor tikus dibagi dalam 4 kelompok perlakuan dan diinduksi $\mathrm{NaCl}$ 5,5\%.

Kelompok I diberikan kontrol positif berupa aquadest, kelompok II diberikan dekok daun zaitun dengan dosis 540mg, kelompok III diberikan dekok daun zaitun dengan dosis 1080mg dan kelompok IV diberikan dekok daun zaitun dengan dosis 2160mg.

Dilakukan uji tekanan darah pada saat pretest sebelum perlakuan dan post test sesudah perlakuan. Data dianalisis menggunakan One way ANOVA diikuti uji Post-hoc menggunakan uji Least Significant Differences (LSD).

\section{HASIL}

\section{Pengukuran Tekanan Darah}

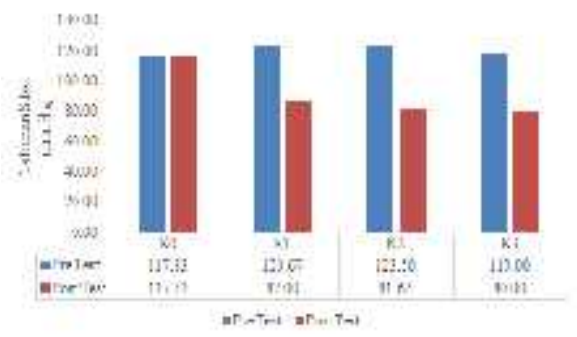

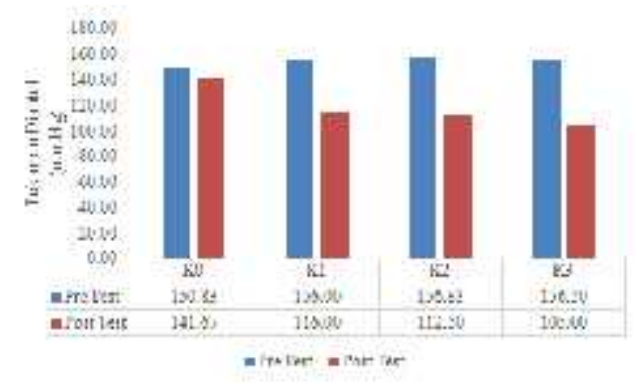

Gambar 2. Rata-rata Tekanan Darah Diastol Tikus Wistar Jantan

\section{Analisis Data}

Hasil uji normalitas menggunakan Shapiro Wilk menunjukkan semua data $p>0,05$ sehingga dapat dikatakan data berdistribusi normal. Hasil uji homogenitas menggunakan uji Levene test menunjukkan semua data $p>0,05$ sehingga dapat dikatakan varians data sama. Hasil uji one way ANOVA menunjukkan tekanan darah sistol $p=0,000$ dan diastol $p=0,001$ sehingga dikatakan terdapat perbedaan bermakna diantara keempat kelompok perlakuan. Setelah dilakukan uji one way ANOVA, dilanjutkan dengan uji Post Hoc Test menggunakan Least Significant Differences (LSD) dan didapatkan hasil masing-masing kelompok memiliki perbedaan yang nyata $(p=0,000)$.

\section{DISKUSI}


Pemberian induksi berupa $\mathrm{NaCl} 5,5 \%$ selama

7 hari dapat meningkatan tekanan sistol dan diastol pada tikus ${ }^{6}$. Induksi larutan $\mathrm{NaCl} 5,5 \%$ bertujuan untuk meningkatkan tekanan darah tikus hingga melebihi normal, tekanan darah pada tikus dikatakan melebihi normal jika tekanan darahnya > $129 / 91 \mathrm{mmHg}^{7}$. Tingginya asupan garam (khususnya natrium) juga diperkirakan berhubungan dengan peningkatan sirkulasi hormon natriuretik yang menghambat trasport natrium intraselular sehingga dapat menyebabkan peningkatan reaktifitas vaskular dan peningkatan tekanan darah, sedangkan pada kelompok perlakuan yang diberikan dekok daun zaitun mengalami penurunan tekanan darah ${ }^{8}$.

Pemberian dekok daun zaitun dengan dosis 540mg, 1080mg dan 2160mg memberikan hasil penurunan tekanan darah sistol dan diastol tikus. Hal tersebut dapat terjadi karena daun zaitun memiliki kandungan oleuropein, dimana kandungan oleuropein memiliki mekanisme kerja menghambat ACE I menjadi ACE II dalam dalam RAA (renin angiotensinaldosteron), penghambatan kerja enzim ACE menyebabkan vasodilatasi pembuluh darah, sehingga tekanan resistensi perifer turun dan dapat menurunkan tekanan darah ${ }^{9,10}$. Oleuropein juga dapat menyebabkan penurunan sekresi ADH (anti diuretik hormon) sehingga absorbsi air berkurang, akibatnya tekanan darah menurun. Pada daun zaitun (Olea europaea L.) memiliki kandungan polifenol yang tinggi dibandingkan dengan buah zaitun maupun minyak zaitun ${ }^{5}$.

Kandungan fenol khususnya oleuropein mampu berfungsi sebagai penghilang endapan-endapan lemak di dalam pembuluh darah dengan menurunkan Low Density Lipoprotein (LDL) dan meningkatkan High Density Lipoprotein (HDL) sehingga mencegah pengerasan pembuluh darah. Selain itu, vitamin E dan metil urat dapat berperan sebagai antioksidan yang juga dapat mencegah pengerasan pembuluh darah ${ }^{11}$.

\section{KESIMPULAN}

Terdapat pengaruh sediaan dekok daun zaitun (Olea europaea L.) dengan dosis 540mg, 1080mg dan $2160 \mathrm{mg}$ terhadap penurunan tekanan darah tikus putih galur wistar (Rattus novergicus strain wistar) jantan yang diinduksi natrium klorida 5,5\%. Penurunan tekanan darah terbesar didapatkan pada kelompok IV dengan dosis $2160 \mathrm{mg}$.

\section{DAFTAR PUSTAKA}

1. Anggara, FHD dan Prayitno, N. (2013). FaktorFaktor Yang Berhubungan Dengan Tekanan Darah Di Puskesmas Telaga Murni, Cikarang Barat Tahun 2012 Jurnal Ilmiah Kesehatan, Vol 5 No. 1 .

2. Infodatin. (2014). Hipertensi. Jakarta: Pusat Data dan Informasi Kementerian Kesehatan RI. 
3. Ting. S. W dan Feng. C. F. (2012). Chinese Medicine Shenfu Injection for Heart Failure : A Systematic Review and Meta-Analysis. Journal of Evidence. Vol. 25.

4. Yogiantoro Mohammad, (2014). Buku Ajar Ilmu Penyakit Dalam. Jilid II, Edisi VI. Jakarta: Interna Publishing.

5. Lockyer, S., Rowland, I., Spencer, J.P., Yaqoob, P., Stonehouse, W. (2015). Impact of phenolic rich olive leaf extract on blood pressure, plasma lipids and inflammatory markers: a randomised controlled trial.Original Contribution. Available from: DOI 10.1007/s00394-016-1188-y [Diakses 13 Juni 2016].

6. Fatimah., Prasetyorini., dan Moerfiah. (2017). Efektifitas Granul Instan Ekstrak Etanol 96\% Buah Sirsak (Annona muricata L.) Ssebagai Antihipertensi Pada Tikus Putih Betina Galur Sprague Dawley. Skripsi. FMIPA, Universitas Pakuan, Bogor.

7. Tista, G. (2011). Pemberian Ekstrak Buah Mengkudu (Morinda citrifolia L) Menurunkan Tekanan Darah Tikus Putih Jantan Galur Wistar (Rattus norvegicus) Yang Hipertensi.

8. Porth, C.M., Marfin. J. (2009). Pathophysiology : Concepts of Altered Health States, eight edition, China: Lippincott Williams dan Wilkins, 505$529,761-783$
9. Omar SH. 2010. Oleuropein in olive and its pharmacological effects. Sci Pharm. 78:133-154.

10. Long, H.S., Tilney, P.M., Wyk, V., (2009). The etnobotany and pharmacognocy of Olea europaea subsp. Africana (Oleaceae). South African Journal of Botany. 76 (2010) 324-331. 